\title{
Evaluation of changes in tear film parameters in patients with advanced and end-stage chronic kidney disease
}

\section{Zmiany w parametrach filmu łzowego u chorych w zaawansowanym i schyłkowym stadiach przewlekłej choroby nerek}

\author{
Agnieszka Gajdowska, Piotr Jurowski \\ Klinika Okulistyki i Rehabilitacji Wzrokowej Uniwersytetu Medycznego w Łodzi \\ Kierownik: prof. dr hab. n. med. Piotr Jurowski
}

Ahstract: $\quad$ Aim: The dry eye syndrome is a common reason for medical appointments. Many factors, including local and systemic disorders or drugs contribute to its occurrence. The aim of the study was to assess changes on the ocular surface in patients with advanced (G4) and end-stage (G5) chronic kidney disease.

Material and methods: Depending on the estimated glomerular filtration rate (eGFR) and the treatment used, the subjects were divided into three groups. Group I: patients with end-stage chronic kidney disease on haemodialysis (chronic kidney disease stage 5); Group II: patients with markedly decreased eGFR (chronic kidney disease, stage 4); Group III: people with normal eGFR. Tear film break-up time test and Schirmer II test were performed. Conjunctival hyperaemia, conjunctival/ corneal calcifications as well as fluorescein and lissamine green staining were assessed.

Results: There were no differences in the prevalence of conjunctival hyperaemia $(p=.147)$, bulbar conjunctival calcifications $(p=.484)$ and corneal calcifications $(p=.687)$. The study groups differed significantly with regards to the prevalence of pingueculae in the bulbar conjunctiva $(p=.024)$, Schirmer II test and tear film break-up time. Corneal staining with fluorescein and lissamine green showed no differences between the study groups $(p=.433$ and $p=.140$, respectively). Both staining methods yielded significant differences with regards to the surface of the bulbar conjunctiva $(p=.002$ and $p=.0001$, respectively).

Conclusions: Advanced chronic kidney disease and haemodialysis negatively affect the tear film. Conjunctival abnormalities appear to be associated with degenerative processes which occur more frequently in patients with chronic kidney disease. There was no difference in the condition of ocular surface and tear film parameters between patients with G4 and G5 of chronic kidney disease.

Key words: $\quad$ chronic kidney disease, ocular surface, tear film break-up time, Schirmer test, fluoresceine, lisamine green.

Abstrakt: $\quad$ Cel: zespół suchego oka jest jedną z najczęstszych przyczyn specjalistycznych porad okulistycznych. Do jego powstania może się przyczynić wiele czynników takich jak schorzenia miejscowe i ogólne oraz stosowanie pewnych grup leków. Celem badania była ocena zmian zachodzących na powierzchni oka u chorych z zaawansowaną postacią (G4) i schyłkową postacią (G5) przewlekłej choroby nerek.

Materiał i metody: zależnie od wartości szacowanego wspótczynnika filtracji kłębuszkowej (eGFR) i stosowanej terapii badane osoby zostały przyporządkowane do trzech grup. Grupa I: hemodializowani chorzy z przewlekłą niewydolnością nerek (stadium 5. przewlekłej choroby nerek), grupa II: chorzy ze znacznym obniżeniem eGFR (stadium 4. przewlekłej choroby nerek), grupa III: osoby z prawidłowym eGFR. Wykonano test pomiaru czasu przerwania filmu łzowego i test Schirmera Il. Oceniono występowanie przekrwienia spojówkowego, zwapnień spojówkowych/rogówkowych oraz barwienie powierzchni oka fluoresceiną i zielenią lizaminową.

Wyniki: nie zaobserwowano różnic w występowaniu przekrwienia spojówkowego ( $p=0,147)$, zwapnień spojówki gałkowej $(p=0,484)$ ani zwapnień rogówki $(p=0,687)$. Badane grupy różiły się istotnie pod względem występowania tłuszczyków ( $p=0,024)$, wyników testu Schirmera II i testu czasu przerwania filmu łzowego. Barwienie rogówki z użyciem fluoresceiny oraz zieleni lizaminowej nie wykazało różnic między grupami (odpowiednio $p=0,433$ i $p=0,140$ ), podczas gdy barwienie spojówek takie różnice uwidoczniło (odpowiednio $p=0,002$ i $p=0,0001$ ).

Wnioski: zaawansowana przewlekła choroba nerek oraz hemodializa wpływają niekorzystnie na jakość i ilość filmu łzowego. Wydaje się, że występowanie nieprawidłowości spojówki można wiązać z istotnie częstszymi procesami zwyrodnieniowymi toczącymi się na powierzchni oka u pacjentów chorujących na przewlekłą chorobą nerek. W badaniu nie wykazano istotnej różnicy w stanie powierzchni oka i parametrach filmu łzowego między chorymi z przewlekłą chorobą nerek w stadium 4 i 5.

Słowa kluczowe: przewlekła choroba nerek, powierzchnia oka, czas przerwania filmu łzowego, test Schirmera, fluoresceina, zieleń lizaminowa.

The authors declare no conflict of interest/ Autorzy zgłaszają brak konfliktu interesów w związku z publikowaną pracą

\section{Introduction}

The issue of lacrimal deficiency in ocular pathology was first presented by Schirmer in 1903 (1); in 1933, Sjögren de- scribed the advanced form of the disorder and called it keratoconjunctivitis sicca (2). Chronic lacrimal deficiency with subsequent chronic inflammation disrupt the morphology of ocular 
surface epithelium. Since the first scientific studies of the dry eye syndrome, which is accompanied by ocular surface abnormalities, a rapid development of diagnostic and therapeutic methods aimed at combating the disorder has taken place. Yet, dry eye syndrome is still one of the most common causes of medical appointments. The most recent reports reveal that above 16 million adult Americans are affected by this syndrome (3). A number of factors, including smoking and some medical treatments with e.g. antihistamines, antihypertensives or sedatives, contribute to the development of dry eye syndrome. Local and systemic disorders, such as connective tissue diseases or chronic kidney disease (CKD), also appear to play a role.

Damage to or a decrease in the number of active nephrons underlie chronic kidney disease. A diagnosis is made on the basis of symptoms of kidney damage which have been present for at least a period of 3 months. The renal damage is determined with the application of the estimated glomerular filtration rate (eGFR). The obtained value allows to identify the following stages of chronic kidney disease: G1 - kidney damage with normal or elevated filtration, G2 - kidney damage with mildly decreased filtration, G3 - kidney damage with moderately decreased filtration, G4 - kidney damage with severely decreased filtration and G5 - kidney failure (4).

An impact of CKD on the severity of dry eye syndrome has not been in the focus of attention. However, due to an increasing incidence of both chronic kidney disease and dry eye syndrome, it is essential to determine the mechanism of morphological changes to the cornea and conjunctiva and identify a potential interrelation between the two.

\section{Aim}

The aim of the study was to assess changes on the ocular surface in a quantitative and qualitative evaluation of the tear film in patients with severe (G4) and end-stage (G5) chronic kidney disease.

\section{Material and methods}

Patients with stage 4 chronic kidney disease, monitored for at least for 6 months and patients with stage 5 (end-stage) chronic kidney disease on haemodialysis were enrolled. The control group consisted of patients with different kidney and/or urinary tract diseases without abnormal eGFR. Exclusion criteria were concomitant systemic diseases, including diabetes mellitus or unstable hypertension, lasting for at least 6 months prior to enrolment. Patients with a history of eye surgery within 6 months prior to enrolment, were also excluded. The study protocol was approved by the Bioethics Committee of the Medical University of Lodz. The research was conducted according to the Declaration of Helsinki. Before study commencement, all subject had provided their informed, written consent to participate. In total, 72 patients (144 eyes) were enrolled. Depending on eGFR values and the received treatment, they were divided into three equal-sized groups. Group I consisted of 24 patients ( 12 males and 12 females) with stage 5 CKD on haemodialysis. Group II consisted of 24 patients (12 males and 12 females) with stage 4 CKD. Group III, i.e. the control group, was made up of 24 patients ( 10 males and 14 females).

A quantitative and qualitative evaluation of the tear film involved a tear film break-up time (TBUT) test and Schirmer II test, which quantifies basic lacrimal secretion. The condition of ocular surface was evaluated, including the degree and type of conjunctival hyperaemia, conjunctival and/or corneal calcifications as well as degree of epithelial staining with fluorescein and lissamine green seen in a slit lamp. The chi-square test, T-student test, Mann-Whitney $U$ test and Dunn's test were used as a part of statistical analyses to determine relationships between the parameters and make comparisons between the groups.

\section{Results}

The eGFR value in Group I did not exceed $15 \mathrm{~mL} / \mathrm{min} / 1.73 \mathrm{~m}^{2}$ (mean value of $6.48 \mathrm{~mL} / \mathrm{min} / 1.73 \mathrm{~m}^{2}$ ). The mean duration on haemodialysis was 34 months (range of 7 to 72 months). In Group II, the eGFR value did not exceed $30 \mathrm{~mL} / \mathrm{min} / 1.73 \mathrm{~m}^{2}$ (mean value of $15.38 \mathrm{~mL} / \mathrm{min} / 1.73 \mathrm{~m}^{2}$ ). In Group III, the eGFR equal to or above $60 \mathrm{~mL} / \mathrm{min} / 1.73 \mathrm{~m}^{2}$ (mean value of $80.92 \mathrm{~mL} / \mathrm{min} / 1.73 \mathrm{~m}^{2}$ ).

A statistical analysis did not reveal differences in prevalence of bulbar conjunctival hyperaemia between the groups $(p=.147)$. The symptom was observed in 11 eyes $(22.92 \%)$ from Group I, 4 eyes (8.33\%) from Group II and 8 eyes (16.67\%) from group III. There was no difference in prevalence of bulbar conjunctival calcifications between Groups II and III $(p=$ .484). Bulbar calcifications were found in 3 eyes $(6.25 \%)$ from Group II and 6 eyes (12.5\%) from Group III. In Group I, there were no cases of bulbar conjunctival calcifications. The prevalence of corneal calcifications was comparable across the three groups $(p=.687)$. It was demonstrated in 18 eyes $(37.50 \%)$, 16 eyes (33.33\%) and 14 eyes $(29.17 \%)$ from groups I, II and III, respectively.

There was a difference $(p=.024)$ between the groups in prevalence of pingueculae on the bulbar conjunctiva. It was present in 25 eyes $(52.08 \%)$ from group II, 19 eyes (39.59\%) from group I and only 12 eyes $(25.00 \%)$ from group III. There were also differences in Schirmer II test between group I and III $(p=.0001)$ as well as group II and III $(p=.003)$, with comparable Schirmer test findings in groups I and II $(p=1.000)$ The mean values of Schirmer test were $8.23 \pm 3.94 \mathrm{~mm}$ (median $7.00 \mathrm{~mm}$ ), $9.02 \pm 5.65 \mathrm{~mm}$ (median $8.00 \mathrm{~mm}$ ) and 12.31 $\pm 4.55 \mathrm{~mm}$ (median $12.00 \mathrm{~mm}$ ) in groups I, II and III, respectively. There were significant differences in TBUT between groups I and III ( $p=.007)$ and groups II and III $(p=.017)$ with comparable TBUT in groups $I$ and $I I(p=1.0)$. The mean TBUT was $7.38 \pm 4.33 \mathrm{~s}$ (median $6.00 \mathrm{~s}$ ) in Group I, $7.65 \pm$ $4.70 \mathrm{~s}$ (median $6.00 \mathrm{~s}$ ) in Group II and $8.90 \pm 2.63 \mathrm{~s}$ (median $9.0 \mathrm{~s})$ in group III.

There were no differences in corneal epithelial staining with fluorescein and lissamine green between the groups $(p=.433$ and $p=.140$, respectively). Corneal fluorescein staining was demonstrated in 21 eyes (43.75\%) from Group I, 15 eyes (31.25\%) from Group II and 17 eyes (35.42\%) from Group III. Corneal lissamine green staining was demonstrated in 6 eyes (12.5\%) from Group I, 8 eyes (16.67\%) from Group II and 2 eyes $(4.17 \%)$ from Group III. On the other hand, there were differences in conjunctival staining with fluorescein and lissamine green between the groups. Conjunctival fluorescein staining was observed more often in groups I ( 34 eyes, $70.83 \%$ ) and II (35 eyes, $72.92 \%$ ) than in group III (20 eyes, 41.67\%) 
$(\mathrm{p}=.002)$, whereas the difference between groups I and II was non-significant. Conjunctical lissamine green staining observed more often in Group I (24 eyes, 50\%) and Group II (22 eyes, $45.83 \%)$ than in Group III (6 eyes, 12.5\%) ( $p=.0001)$, whereas the difference between groups I and II was non-significant.

\section{Discussion}

Disturbance of calcium and phosphate metabolism observed in patients with CKD and confirmed in many research reports might have a considerable effect on eye surface. Morphological changes mainly include small calcifications, involving both the cornea and conjunctiva. Initially, it was reported that such changes occur in patients receiving long term haemodialysis. This study, however, reveals that they are also present in patients with earlier stage CKD, who do not need renal replacement therapy yet.

Calcium deposits are usually localized in the limbo-conjunctival area, within the palpebral fissure. This is associated with the fact that tear film is a medium for the ocular surface epithelium to return carbon dioxide from the interpalpebral area to the environment. When $\mathrm{pH}$ changes into alkaline, the substance gets less soluble. Consequently, calcium salts in the cornea, corneal limbus and conjunctiva get precipitated. Vignanelli and Stucchi confirmed that the process is promoted by elastotic degenerative changes in subepithelial connective tissue (5). Calcifications found in dialysed patients are both dystrophic and "metastatic" (6). An article published by Porter and Crombie (7) provides a more accurate grading system for corneoconjunctival calcifications. Their severity scale used involves: no calcifications, conjunctival calcifications and corneoconjunctival calcifications of varying degree.

Corneoconjunctival calcifications can also be associated with other disorders. Özdemir et al. noted that the degree of calcifications correlates with dry eye symptom severity in patients on haemodialysis (8). Hsiao et al. confirmed a significant association between the presence of calcifications, their severity and mortality of patients on haemodialysis (9).

Calcifications usually develop over a longer time. There are very few reports on relatively rapid development, lasting only a few months. The process starts with calcific deposits forming the girdle of Vogt. Next, they turn into central corneal opacity. The final stage of the progress involves extensive deposits forming band keratopathy. The progression of these changes was shown to be associated with increased plasma phosphate levels and later also with an increased free calcium ion level (10).

While conducting a study in patients on haemodialysis, Bogorodzki et al. observed not only calcifications but also palisade vascularization at the corneal limbus, which penetrated 1-3 mm into the cornea. They concluded that these abnormalities did not affect visual acuity (11). In our study, there were no between-group differences in prevalence of corneal calcifications. Interestingly, although pingueculae were present more often in patients on haemodialysis than in other patients with CKD, it was not true for bulbar conjunctival calcifications. As noted previously, conjunctival degenerative changes contribute to the formation of calcifications. A relatively short duration of renal replacement therapy (34 months) in Group I might account for these findings. On the other hand, good quality nephrological care might have positively affected the ocular surface of CKD patients. It should be noted that most studies on corneal and conjunctival changes in CKD patients were conducted in the 1970's and 1980's. Since then, not only have we become more knowledgeable in the pathophysiology of CKD progression but first of all, we have improved methods of renal replacement therapy, which has enabled elimination of multiple complications.

Authors of early publications on ocular changes in patients on long-term haemodialysis reported intensive conjunctival hyperaemia as a common symptom $(7,12)$. Klaassen-Broekem and van Bijsterveld identified three types of hyperaemia, i.e. pingueculitis, extensive conjunctival hyperaemia and extensive conjunctival and episcleral hyperaemia. In an attempt to identify the underlying causes, they concluded that it resulted from disturbances of calcium and phosphate metabolism $(13,14)$. Berlyne and Shaw (15) confirmed a relationship between the presence of hyperaemia and increased levels of inorganic phosphates. There were no cases of hypercalcaemia in their study group. A decreased blink reflex $(16,17)$, exhaled air, containing di- and tri-methylamine which is "harmful" for the ocular surface, hydrogen peroxide as well as nitrogen oxide, which has vasodilatory properties, are believed to contribute to the "red eye" symptom (18). Interestingly, Berlyne and Shaw (15) did not observe an increase in conjunctival hyperaemia in patients with advanced stages of CKD, which seems surprising when considering significant changes in the quality and quantity of tear film in CKD patients. It was probably explained by Klaassen-Broekem, who demonstrated an association between the degree of conjunctival hyperaemia in patients with CKD and the presence of calcium deposits on the ocular surface (13). Since an increased prevalence of corneal or conjunctival calcifications was not confirmed, the involvement of calcium salts, found in the ocular surface epithelium, in conjunctival hyperaemia in patients with renal failure cannot be ruled out.

Current studies on the condition and parameters of tear film in patients on haemodialysis have brought in other interesting observations. Increased osmolality of the tear film prior to haemodialysis, followed by its slight hemodialysis-induced decrease, observed by Charlton et al., can provide an explanation for a decreased level of urea in tears, which is initially high. The same study also implies that the patients hardly complain about ocular dryness due to potential protective, moisturising and mucolytic effect of urea on ocular surface epithelium (19). Özdemir et al. analysed in detail the condition of ocular surface and parameters of tear film in patients on haemodialysis. They observed decreased TBUT, increased rose bengal corneal and conjunctival staining as well as higher prevalence of symptoms typical of dry eye syndrome. They demonstrated a correlation between epithelial metaplasia and bengal rose staining (8). Furthermore, other studies pointed out that patients with CKD demonstrate excessive keratosis of the conjunctival epithelium, which probably occurs due to impaired vascularization and chronic inflammation on the ocular surface. Importantly, these studies indicated that inflammation was closely related to microcrystals (calcifications) found in the conjunctiva and cornea (20), although there are studies to contradict these assumptions (21).

Dursun demonstrated a loss of goblet cells of the conjunctival epithelium (22), whereas Jung (23), Özdemir (8) and Türk- 
cü (24) showed epithelial metaplasia, decreased TBUT and decreased basic tear secretion in eyes of patients with CKD. Additionally, Demir et al. found that the severity of squamous epithelial metaplasia of the conjunctiva was associated with the duration of haemodialysis (25). Furthermore, it has been pointed out that patients in advanced stages of CKD can feel discomfort due to changes in tear secretion and distribution on ocular surface, which are secondary to conjunctival degeneration, including pingueculae and pterygium. Interestingly, in our study, patients with stage 4 (Group II) and 5 (Group I) CDK developed pingueculae of bulbar conjunctiva more often than CDK-free controls. Decreased TBUT in patients with advanced stages (G4 and G5) of chronic kidney disease, observed in our study, has been confirmed by other published studies $(8,23)$. The underlying causes of TBUT abnormalities in patients on haemodialysis include a reduced count of conjunctival goblet cells $(22)$, conjunctival squamous epithelial metaplasia $(8,24)$ and increased incidence of demodicosis (26).

Benitez-del-Castillo et al. proposed that basic tear secretion results from constant, "subconscious" stimulation of the corneal surface (27). They observed abnormal values of the Schirmer II test in patients in advanced stages (G4 and G5) of chronic kidney disease. In this case, decreased basic tear secretion may be associated with neural conduction disturbance leading to development of peripheral neuropathy and reduced corneal sensitivity, as demonstrated by Kirshan (28).

The reason why we used lissamine green was that its staining range was comparable to that of rose bengal but the tolerance profile was better (29). Positive lissamine green staining of bulbar conjunctiva indicates focal epithelial metaplasia (30), which was also confirmed for rose bengal (8). Single fluorescein-stained foci in the bulbar conjunctiva, observed in patients with stages 4 and 5 CKD might have been caused by microcalcifications which damage the epithelium. Abrams (12) made similar observations with regards to the occurrence corneal changes. However, this explanation seems insufficient as we did not demonstrate bulbar conjunctival calcifications in patients on haemodialysis. Submicroscopic nature of conjunctival calcifications may be taken into consideration but an impaired blinking reflex might provide an alternative explanation $(19,20)$. It is difficult to explain this phenomenon due to lack of noticeable changes within corneal epithelium.

\section{Conclusions}

Advanced CKD and haemodialysis used in end stage CKD negatively affect the quality and amount of tear film. Conjunctival abnormalities appear to be associated with degenerative processes, which occur significantly more often on the ocular surface of patients with CKD. We did not demonstrate a difference in the condition of ocular surface and tear film parameters between patients with G4 and G5 of chronic kidney disease.

\section{Źródło finansowania - grant MNiSW: NN 402458537}

\section{References:}

1. Schirmer 0: Studien zur physiologie und pathologie der tranen-absonderung und tranenabfuhr. Graefes Arch Clin Exp Ophthalmol. 1903; 56: 197-291.
2. Sjögren H: Zur Kenntnis der Keratoconjunctivitis sicca (Keratitis filiformis bei hypofunktion der Tranendrusen). Acta Ophthalmol Suppl. 1933; 11: 1.

3. Farrand KF, Fridman M, Stillman IÖ, Schaumberg DA: Prevalence of Diagnosed Dry Eye Disease in the United States Among Adults Aged 18 Years and Older. Am J Ophthalmol. 2017 Oct;182: 90-98.

4. Levin A, Stevens PE, Bilous RW, Coresh J, de Francisco ALM, de Jong PE, et al.: Kidney Disease: Improving Global Outcomes (KDIGO) CKD Work Group: KDIGO 2012 clinical practice guideline for the evaluation and management of chronic kidney disease. Kidney Int Suppl. 2013; 3(1): e150.

5. Vignanelli M, Stucchi CA: Les calcifications conjonctivales chez les patients en hémodialyse chronique: étude morphologique, clinique et épidémiologique. J Fr Ophtalmol. 1988; 11(6-7): 483-492.

6. Santillo C, Bonucci E, Fayyad F, Silvestrini G, Terzigni R: Etude morphologique de la conjonctive chez les malades dialyses. Bull Mém Société Fr Ophtalmol. 1981; 93: 151.

7. Porter R, Crombie AL: Corneal and conjunctival calcification in chronic renal failure. Br J Ophthalmol. 1973; 57(5): 339.

8. Özdemir M, Bakaris S, Özdemir G, Buyukbese MA, Cetinkaya A: Ocular surface disorders and tear function changes in patients with chronic renal failure. Can J Ophthalmol Can Ophtalmol. 2004; 39(5): 526-532.

9. Hsiao C-H, Chao A, Chu S-Y, Lin K-K, Yeung L, Lin-Tan D-T, et al.: Association of severity of conjunctival and corneal calcification with all-cause 1-year mortality in maintenance haemodialysis patients. Nephrol Dial Transplant. 2011; 26(3): 1016-1023.

10. Klaassen-Broekema N, van Bijsterveld OP: Rapid progression of band-shaped keratopathy with early central localisation in a patient on chronic dialytic treatment. Eur J Ophthalmol. 1993; 4(2): 126-129.

11. Bogorodzki B, Grałek M, Skrzycka A: Zmiany w układzie wzrokowym u chorych przewlekle dializowanych. Klin Oczna. 1987; 89: 187-189.

12. Abrams JD: Corneal and other ocular findings in patients on intermittent dialysis for renal failure. Proc R Soc Med. 1966; 59(6): 533.

13. Klaassen-Broekema N, van Bijsterveld OP: Diffuse and focal hyperaemia of the outer eye in patients with chronic renal failure. Int Ophthalmol. 1993; 17(5): 249-254.

14. Klaassen-Broekema N, van Bijsterveld OP: The role of serum calcium in the development of the acute red eye in chronic renal failure. Eur J Ophthalmol. 1994; 5(1): 7-12.

15. Berlyne GM, Shaw AB: Red eyes in renal failure. The Lancet. 1967; 289 (7480): 4-7.

16. Resende LAL, Caramori JCT, Kimaid PAT, Barretti P: Blink reflex in end-stage-renal disease patients undergoing hemodialysis. $\mathrm{J}$ Electromyogr Kinesiol. 2002; 12(2): 159-163.

17. Strenge H: The blink reflex in chronic renal failure. J Neurol. 1980; 222(3): 205-214.

18. Ghafarieh AR, Chamacham T: Effects of noxious compounds in exhaled breath air as a potential mechanism causing "red eye" in renal failure patients. Iran J Med Hypotheses Ideas. 2007; 1(1): 7.

19. Charlton JF, Schwab IR, Stuchell R: Tear hyperosmolarity in renal dialysis patients asymptomatic for dry eye. Cornea. 1996; 15(4): 335-339. 
20. Berlyne GM: Microcrystalline conjunctival calcification in renal failure: a useful clinical sign. The Lancet. 1968; 292(7564): 366-370.

21. Klaassen-Broekema N, van Bijsterveld OP: The red eye of renal failure: a crystal induced inflammation? Br J Ophthalmol. 1992; 76(10): 578-581.

22. Dursun D, Demirhan B, Oto S, Aydin P: Impression cytology of the conjunctival epithelium in patients with chronic renal failure. Br J Ophthalmol. 2000; 84(11): 1225-1227.

23. Jung JW, Yoon MH, Lee SW, Chin HS: Effect of hemodialysis (HD) on intraocular pressure, ocular surface, and macular change in patients with chronic renal failure. Graefes Arch Clin Exp Ophthalmol. 2013; 251(1): 153-162.

24. Türkcü G, Temiz G, Yüksel H, Ta $M$, Tunç $N$, et al.: Ocular surface findings in chronic renal failure. Eur J Gen Med. 2014; 11(3): 148-152.

25. Demir N, Altay M, Özer E, Ünlü N, Duranay $M$, Üstün $H$, et al.: Duration of renal failure as risk factor for conjunctival squamous metaplasia. Acta Cytol. 2008; 52(3): 309-312.

26. Karincaoglu Y, Esrefoglu Seyhan M, Bayram N, Aycan 0, Taskapan $\mathrm{H}$ : Incidence of Demodex folliculorum in patients with end stage chronic renal failure. Ren Fail. 2005; 27(5): 495-499.
27. Benitez-del-Castillo JM, del Rio T, Iradier T, Hernández JL, Castillo A, Garcia-Sanchez J: Decrease in tear secretion and corneal sensitivity after laser in situ keratomileusis. Cornea. 2001; 20(1): 30-32.

28. Krishnan AV, Phoon RKS, Pussell BA, Charlesworth JA, Kiernan MC: Sensory nerve excitability and neuropathy in end stage kidney disease. J Neurol Neurosurg Psychiatry. 2006; 77(4): 548-551.

29. Manning FJ, Wehrly SR, Foulks GN: Patient tolerance and ocular surface staining characteristics of lissamine green versus rose bengal. Ophthalmology. 1995; 102(12): 1953-1957.

30. Pflugfelder SC, Tseng SC, Yoshino K, Monroy D, Felix C, Reis BL: Correlation of goblet cell density and mucosal epithelial membrane mucin expression with rose bengal staining in patients with ocular irritation. Ophthalmology. 1997; 104(2): 223-235.

The paper was originally received 24.06.2018 (KO-00169-2018)/ Praca wpłynęła do Redakcji 24.06.2018 r. (K0-00169-2018)/ Accepted for publication 27.12.2018/

Zakwalifikowano do druku 27.12.2018 r.

Reprint requests to (Adres do korespondencji): lek. Agnieszka Gajdowska Klinika Okulistyki i Rehabilitacji Wzrokowej USK im. WAM ul. Żeromskiego 113, 90-549 tódź e-mail: agnieszkajgajdowska@gmail.com

\section{Polskie Towarzystwo Okulistyczne www.pto.com.pl}

